\title{
Bone histology of Protoceratops andrewsi from the Late Cretaceous of Mongolia and its biological implications
}

\author{
Łucja Fostowicz-Frelik and Justyna Słowiak \\ Acta Palaeontologica Polonica 63 (3), 2018: 503-517 doi:https://doi.org/10.4202/app.00463.2018
}

Protoceratops andrewsi is one of the best known and abundant ornithischian dinosaurs from the Djadokhta Formation (Late Cretaceous, Mongolia) and a subject of many morphological studies. Here we present the first study of its bone tissue (from the long bones, frill, and rib), describing microstructure, extent of remodeling, and growth tempo changes in ontogeny. Several specimens representing juvenile, subadult, and adult age stages have been studied. In general, paleohistology of Protoceratops is quite uniform throughout ontogeny, showing basic fibrolamellar bone complex with prevalence of woven-fibered bone and scarce remodeling. In adults the parallel-fibered bone matrix forms distinct although irregular zonation in the cortex until dominating it. The bone displays noteworthy abundance of fossilized fibers (including Sharpey's fibers), which apparently strengthen the tissue and enhance its elasticity. Growth tempo increased in the studied femora of Protoceratops at the subadult stage, which suggests changes in bone proportions (i.e., elongation of the hind limbs) in a similar manner as it was observed in a more basal Psittacosaurus.

Key words: Dinosauria, Ornithischia, Ceratopsia, paleohistology, ontogeny, growth tempo, Cretaceous, Mongolia.

Łucja Fostowicz-Frelik [1]fost@twarda.pan.pl], Institute of Paleobiology, Polish Academy of Sciences, ul. Twarda 51/55, 00-818 Warsaw, Poland; and Key Laboratory of Vertebrate Evolution and Human Origins, Institute of Vertebrate Paleontology and Paleoanthropology, Chinese Academy of Sciences, Beijing 100044, People's Republic of China. Justyna Słowiak [justyna.slowiak@twarda.pan.pl], Institute of Paleobiology, Polish Academy of Sciences, Twarda 51/55, 00-818 Warsaw, Poland. 
This is an open-access article distributed under the terms of the Creative Commons

Attribution License (for details please see creativecommons.org), which permits unrestricted use, distribution, and reproduction in any medium, provided the original author and source are credited.

FoF Full text $(2,905.2 \mathrm{kB})$ 